\title{
EDITORIAL
}

\section{VETERAN ORGANISATIONS - ARE THEY EVEN NEEDED?}

When discussing veterans and veteran organisations, one usually first thinks of the past. We first think of different wars and their consequences. We think of all those who participated in those wars and were lucky enough to stay well and unharmed. And we think of all those who came out with different issues, be it physical or emotional; however there are even more of those who have had to deal with both.

Although we are today very lucky and the wars on the flanks of the European Union are mainly the subject of historical discussions, we in the Editorial Board of the Contemporary Military Challenges decided to dedicate one of the thematic issues to veteran organisations and their role in the modern society.

Military veterans form a constituent part of Slovenian, broad European and global society. They are identified according to different wars and individual armed conflicts they participated in. In different settings, they are treated and organised in very various ways; even their impacts on the formation of the modern society vary. Still, to some of them, nothing of this applies, because they fought on the wrong side. However, the wrong side no longer represents a problem everywhere, as it used to be the case, since the perceptions of conflict from the past have been transformed into fruitful cooperation for the future.

The question of veteran organisations or the question whether or not they are even needed, thus remains a rhetorical one, especially considering the emergence of new veteran organisations comprising veterans of different international operations and missions, even in the countries, which otherwise do not even have other (war) veterans.

The thematic issue in front of you was prepared in cooperation with Vladimir Prebilič as guest editor and some of the participants of the international panel discussion held in Ljubljana last summer. 
Vladimir Prebilič opens this issue with his article Veterans imperative today, where he inform us about the basic terms of veterans, who they are, what is the veteran imperative and how it is manifested in modern societies, especially those where the armed forces were professionalized, which marginalized the topics related to national security and the military.

Veterans in the previous century in Romania are discussed by Carmen Sorina Rijnoveanu in her article The reappraisal of veterans' status in post-communist societies - Romania's case. At first, Romania joined the German Reich in its fight against the Soviet Union, but eventually came under the rule of the latter, which was not a favourable situation for some of the veterans. After 1990, the situation again changed.

After the Second World War, the veterans in Germany and France represented a great challenge, since despite the fact that they had fought on the opposite sides, they managed to develop successful cooperation. This interesting phenomenon is discussed by Jörg Echternkamp in his article From foe to friend? Veterans as a driving force of international reconciliation after the Second World War.

Veterans and philanthropy after the Great War: role and representations from the Carnegie endowment for international peace is the title of the article by Nadine Akhund-Lange, who engaged in the research of an organisation, which was established after the First World War mainly with the aim to provide for war veterans and war disabled. You can read more about how successful it was in its endeavours in her article.

Valerija Bernik in her article Women Veterans of the Second World War writes about the mobilisation of women in the armed forces of different countries, who after the conflicts never enjoyed the same status as their male counterparts, neither formally nor socially.

The article titled The long road towards an official Danish veterans 'policy, 1848-2010 was written by Niels Bo Poulsen and Jakob Brink Rasmussen. They write about Danish veteran policy, which was regulated with the first official document in this field as late as in 2010. Several different factors influenced the fact that Denmark had not properly regulated this area beforehand, but the most interesting ones are certainly those which have recently facilitated this change.

Alojz Šteiner and Tomaž Čas wrote about the regulation of veteran organisations in Slovenia. In their article Patriot and veteran organisations - the case of Slovenia they write about several Slovenian veteran organisations and their role in the society. Those organisations are relatively numerous. They have different programmes and are mostly very active.

We wish you plenty of interesting reading and a nice summer! 